\title{
Análise temporal do uso e ocupação do terreno do Parque Estadual do Biribiri e de sua Zona de Amortecimento, município de Diamantina, Minas Gerais
}

\section{Temporal analysis from the land use and occupation of the Biribiri State Park and its Buffer Zone, Diamantina, Minas Gerais}

\author{
Marcelino Santos Morais \\ Doutor em Geografia, Professor do Departamento de Geografia \\ Universidade Federal dos Vales do Jequitinhonha e Mucuri - UFVJM \\ morais.marcelino@gmail.com \\ Bernardo Machado Gontijo \\ Doutor pelo CDS/UnB \\ Prof. Adjunto do Instituto de Geociências, UFMG \\ gontijobm@yahoo.com.br \\ Danielle Piuzana \\ Doutora em Geologia, UnB \\ Prof. Adjunta da Faculdade Interdisciplinar em Humanidades, UFVJM \\ dpiuzana@yahoo.com.br
}

\begin{abstract}
Artigo recebido para revisão em 23/09/2015 e aceito para publicação em 05/10/2015
\end{abstract}
\begin{abstract}
Resumo
O Parque Estadual do Biribiri, situado no Alto Vale do Jequitinhonha, Minas Gerais, caracteriza-se por aspectos geológicos, morfopedológicos e geoambientais que lhe confere atributos de grande potencialidade econômica, mas também de extrema fragilidade, fato que justificou a sua criação. Tal cenário gerou o o objetivo geral deste trabalho, que é analisar a evolução temporal do uso e ocupação do terreno na área do parque assim como em sua zona de amortecimento. Para fins de metodologia a pesquisa abarcou revisão bibliográfica, o reconhecimento de campo da área do parque e entorno e a realização de mapas de uso e ocupação do terreno no período entre 1991 e 2011 pelo software Multispec a partir de imagens LANDSAT 5 com composição de bandas R5G4B3. A classificação paisagística, constituída por fitofisionomias nativas predominantes na região, foi: Formação Savânica/Florestal Associada; Formação Campestre, Afloramento Rochoso. A classe caracterizada por ação antrópica foi denominada Solo Exposto. Em áreas do parque há uma tendência de estabilização da Formação Campestre e um decréscimo da classe Formação Savânica/Florestal Associada, condicionada ao tempo necessário a sua regeneração, uma vez que as imagens analisadas foram obtidas nas estações mais secas aliadas a recorrência de incêndios florestais. Evidenciou-se uma tendência de estabilização para a classe Solo Exposto. Mesmo em período anterior a criação do parque essa classe apresentou menos de $1 \%$ em sua área total. A realidade exposta pela análise temporal do uso e ocupação do terreno discorda das informações desta natureza contida no Plano de Manejo do parque o qual afirma que atividades de cunho tradicional foram fatores determinantes para a perda de qualidade ambiental na área do parque.
\end{abstract}

Palavras-chave: Unidades de Conservação. Fitofisionomias do Cerrado. Dinâmica da paisagem.

\begin{abstract}
The Biribiri State Park, located in the Upper Jequitinhonha Valley, Minas Gerais, is characterized by geological, morphopedological and geoenvironmental features giving it attributes of great economic potential, but also extremely fragile, a fact that justified its creation. This scenario led to aim of this study, which is to analyze the evolution of land use and occupation in the area park as well as its buffer zone. For methodology the purpose encompassed literature review, the recognition of the park and surrounding area of the field and conducting maps of land use and occupation in the period between 1991 and 2011
\end{abstract}


by Multispec software from Landsat 5 images with composition bands R5G4B3. The landscape classification, consisting of native vegetation types in the region, was: Savanna/Forestry Associate Formation; Campestre Formation, Rocky Outcrop. The class characterized by human action was called Solo Exposed. The park area, for the period 1991/1994, there is a tendency of stabilization of Campestre Formation and a decrease of Savanna/Associated Forest Formation. This reduction is due to the time required for its regeneration since the images analyzed were obtained in the drier seasons combined recurrence of forest fires. The temporal maps showed a trend of stabilization for Exposed Soil class. Even in the period before the creation of the park this category was less than $1 \%$ in your area. The reality exposed by temporal analysis of the land use and occupation disagrees with the information in question contained in Management Plan of the Biribiri Park, which states that traditional nature activities were determining factors for the loss of environmental quality in areas of the parks.

Keywords: Protected Areas. Cerrado vegetation types. Landscape dynamics.

\section{INTRODUÇÃO}

O Parque Estadual do Biribiri (PEBI) foi criado em 22 de Setembro de 1998 com o objetivo de proteger a fauna e flora regionais, as nascentes dos rios e córregos da região, além de criar condições ao desenvolvimento de pesquisas e estudos científicos e alternativas de uso racional dos recursos naturais (MINAS GERAIS, 1998).

As áreas abrangidas pelo PEBI e sua Zona de Amortecimento (ZA) possuem respectivamente 17.000ha e 70.000ha. (Figura 1). Geomorfologicamente, o Parque Estadual do Biribiri (PEBI) e sua Zona de Amortecimento (Z.A.) estão presentes na porção Norte do Planalto de Diamantina (Figura 2).

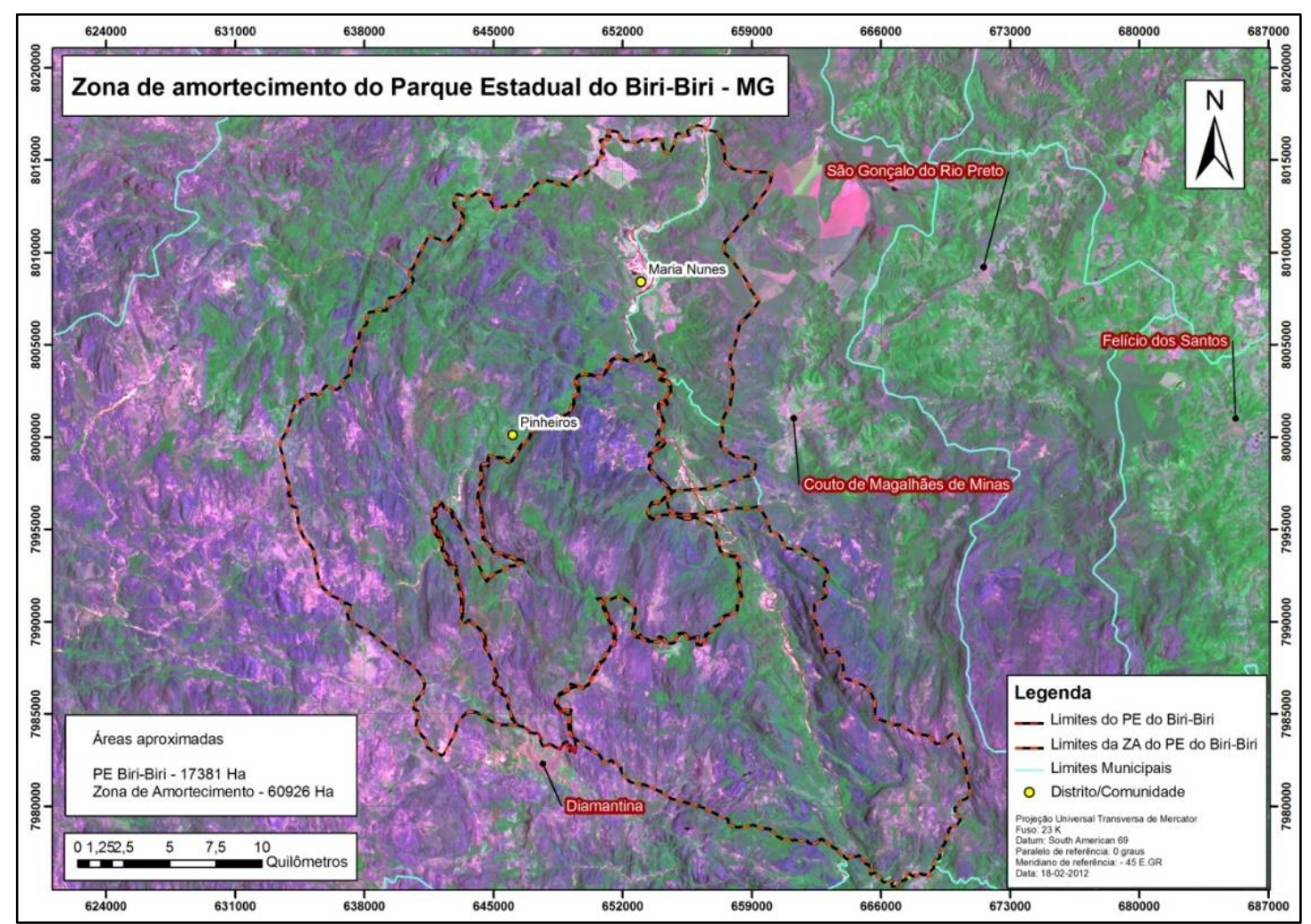

Figura 1: Delimitação da Zona de Amortecimento do Parque Estadual do Biribiri segundo o STCP (2004a). 
Os aspectos morfológicos e funcionais da região lhes conferem atributos naturais altamente valorizados do ponto de vista socioeconômico, no que concerne às atividades turísticas (ecoturismo e educação ambiental com a visitação às áreas naturais e históricas) e ao aproveitamento racional dos recursos hídricos. De acordo com Abreu (1982), Saadi (1995), Melgaço (1999), Guimarães (2004), Silva et al. (2005), dentre outros, os aspectos geológicos, morfopedológicos e geoambientais globais de superfície lhes conferem atributos de grandes potencialidades econômicas, mas também de extrema fragilidade.

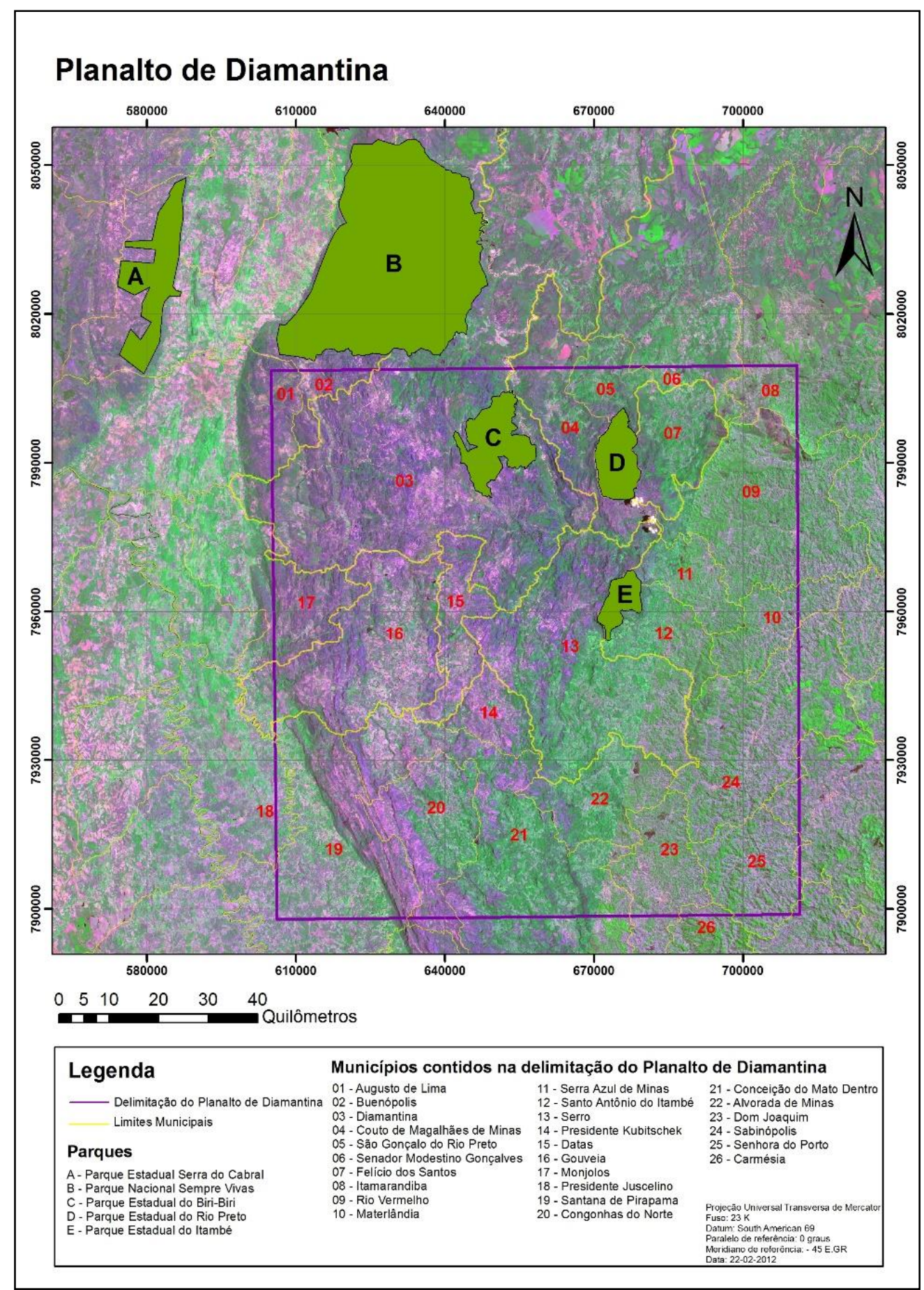

Figura 2: Esboço cartográfico da delimitação do Planalto Diamantina com delimitação em amarelo dos munícipios da região. Modificado de Morais (2014). 
De acordo com Abreu (1982) a ação humana valorizou, desde o início, exatamente os escombros da morfogênese regional, que continham em si o diamante e o ouro, cuja exploração deu a tônica em todo o sistema territorial implantado na região, desde os primórdios de seu povoamento. A sinergia edificada entre as feições macro-morfológicas e os ricos biomas, constituem paisagens de valor estético, científico e ecológico incomensurável, mas extremamente frágeis. Este cenário edifica interpretações distintas no que se refere o uso e gestão do espaço.

Tendo por base a fragilidade ambiental norteia-se regionalmente a qualificação dessa região como área prioritária para programas de preservação ambiental, fato esse comprovado pela criação de um Mosaico de Unidades de Conservação do Alto Jequitinhonha -Serra do Cabral (AZEVEDO et al., 2009) representado pela Figura 3.

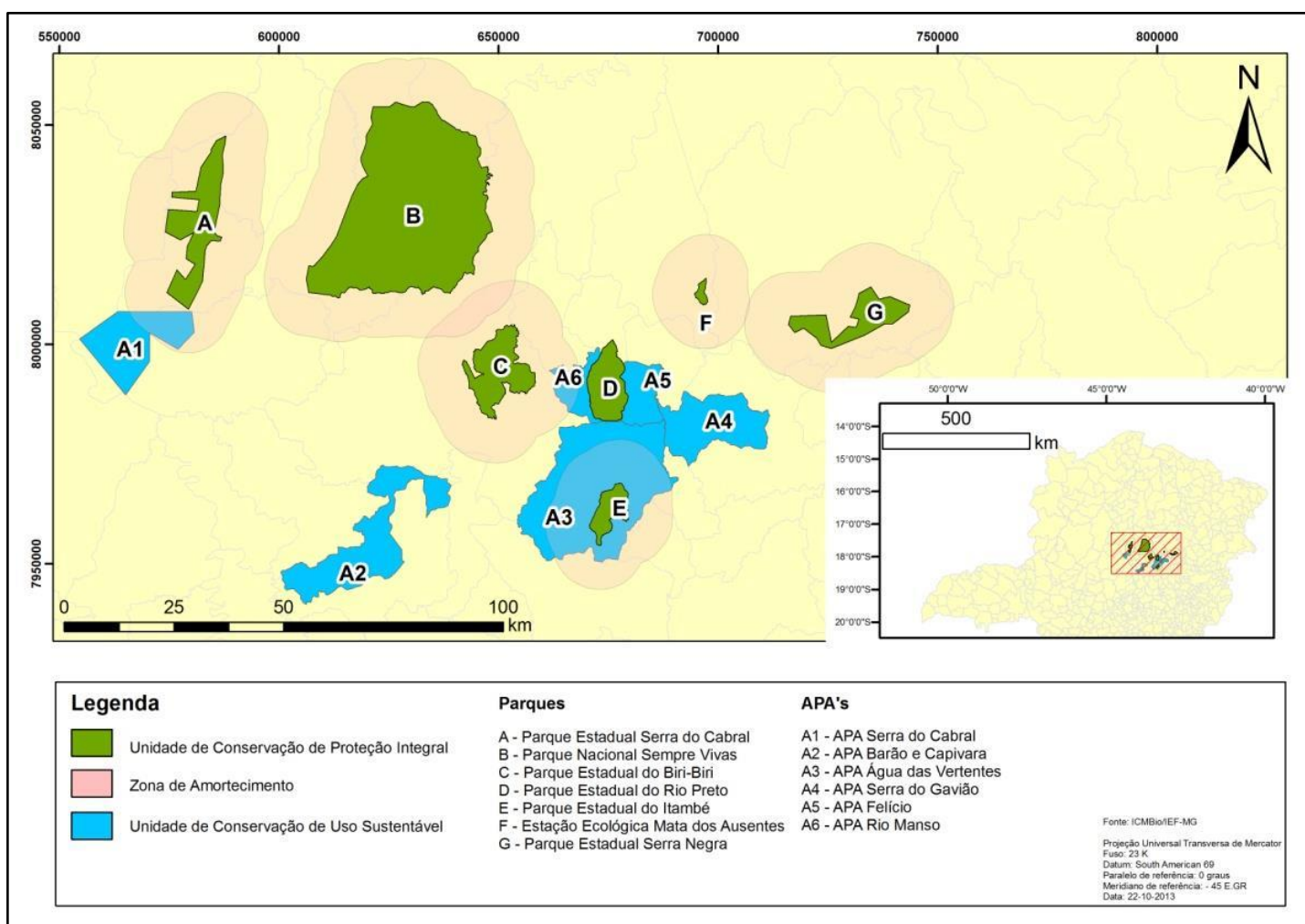

Figura 3: Área de abrangência do Mosaico de UC's do Alto Jequitinhonha-Serra do Cabral. Retirado de Morais et al.. (2014).

Por outro lado, é importante o entendimento de que as diversidades biológicas e geológicas da região condicionaram a construção de uma singular realidade sociocultural a qual se expressa, ou se expressou, pela tradição do extrativismo mineral e florístico sustentável.

As modificações ocorridas no PEBI e em sua ZA, vinculam-se ao extrativismo vegetal e mineral e à pecuária extensiva. Soma-se a isso pressões antrópicas típicas do urbano que margeiam a UC. Nessa realidade, surge um ambiente de conflito entre as comunidades de entorno e o PEBI, esse conflito é agravado pelo desconhecimento sobre os processos de criação e implantação dessa UC e 
pelo questionamento se realmente o parque está promovendo a recomposição ambiental de sua área e de sua Z.A.

Diante deste conflito, o presente trabalho tem por objetivo analisar temporalmente o Uso e Ocupação do Terreno do Parque Estadual do Biribiri e ZA, visando auxiliar nas discussões de gestão da UC e dar subsídios aos questionamentos das comunidades.

\section{MATERIAIS E MÉTODOS}

A caracterização e classificação vegetacional, pedológica e de modelagem do terreno predominantes no PEBI tiveram como base os trabalhos de Silva (2004), Silva (2012), STCP (2004 a,b) e Ribeiro e Walter (1998) além do banco de dados disponibilizado IEF que possibilitou a elaboração de mapas de unidades pedológicas, vegetação e modelagem neste trabalho. Atividades de campo foram realizadas com o intuito de aferir as informações obtidas.

Quanto a análise temporal de uso e ocupação do terreno, os mapas espacializaram as áreas do parque bem como sua zona de Amortecimento. Apesar de individualizada nas interpretações das imagens de satélites, a observação da paisagem possibilitada nas atividades de campo realizadas como descrito no item anterior auxiliou na definição dos parâmetros de análise.

Foram confeccionados 5 mapas de Uso e Ocupação de Terreno, tendo como fonte primária de informação imagens Landsat 5, adquiridas Instituto Nacional de Pesquisas Espaciais (INPE), para auxiliar no entendimento da dinâmica espacial da região em análise.

De acordo com Yang (2002), a análise multi-temporal de imagens de satélites pode ser utilizada nas interpretações da evolução do uso do terreno e cobertura vegetal, possibilitando a detecção de padrões de mudança ao longo do tempo, tanto qualitativa quanto quantitativamente. Os perídos estabelecidos para análise compreenderam um intervalo de 5 anos. Tiveram início em momento que antecedeu a criação do PEBI e fim em 2011, ano que se encerrou o imageamento pelo Landsat 5. A área delimitada foi recortada e exportada para o Multispec com as combinações R5G4B3 para realizar a classificação multiespectral supervisionada.

Segundo Centeno (2004), o processo de classificação é iniciado com a definição das classes conhecidas ou de interesse do usuário. Neste sentido optou-se por 4 classes após várias tentativas que levaram a mapeamentos complexos, de difícil interpretação e imprecisos, devido a confusão espectral. As classes definidas foram: 1) Formação Savânica/ Florestal associada, caracterizadas por áreas de vegetação natural com formação densa; 2) Formação Campestre, caracterizada por campos limpos ou rupestres; 3) Afloramento Rochoso, caracterizado em áreas onde é possível diagnosticar o estrato rochoso e 4) Solo Exposto, típico de áreas sem cobertura vegetal e/ou com presença de areia (Figura 4). 


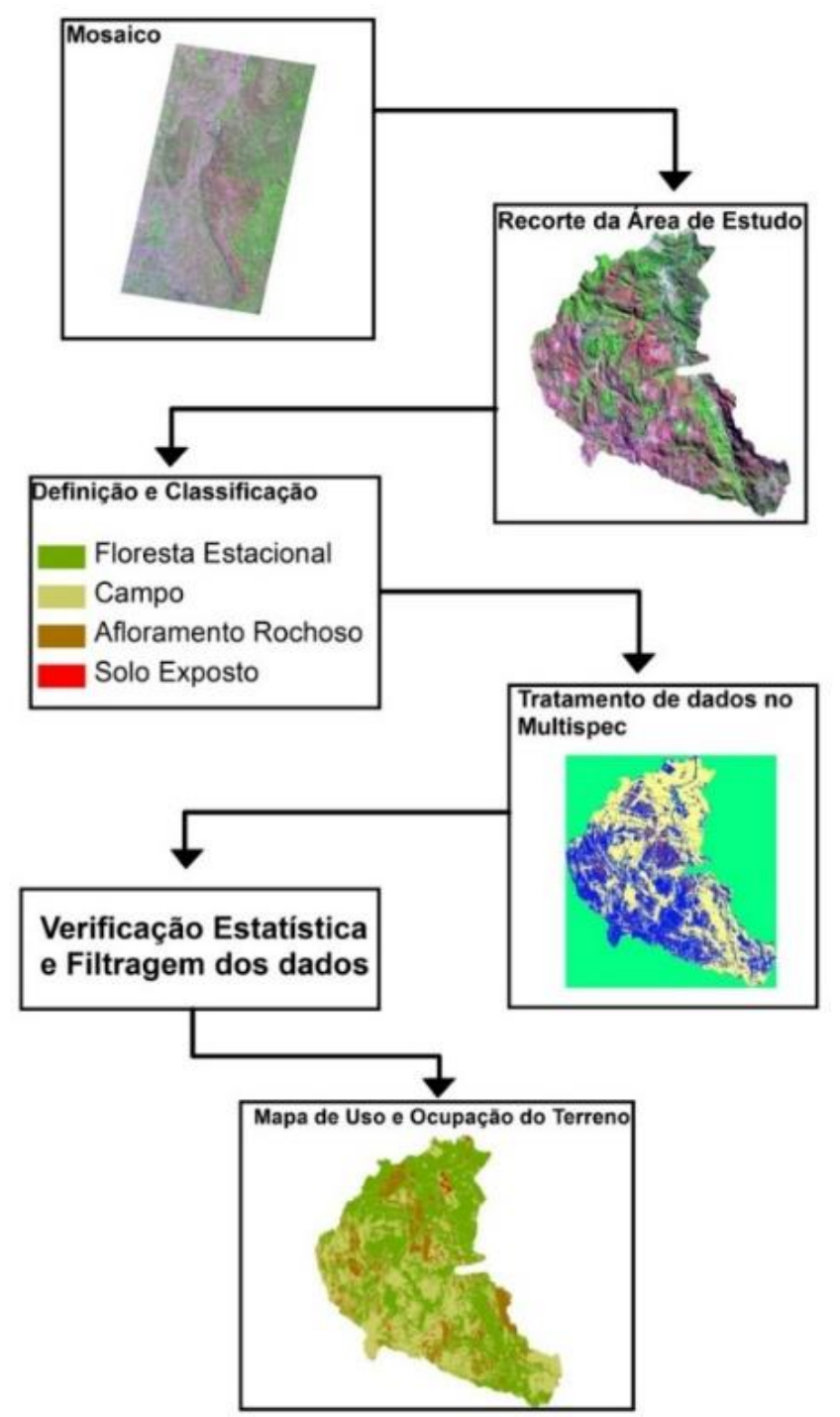

Figura 4: Abordagem metodológica e principais fases de execução.

Cabe ressaltar que Formação Savânica e a Formação Florestal foram unificadas por apresentarem, tanto na escala de mapeamento e quanto na qualidade da imagem, comportamentos bastante parecidos, o que dificultou o desempenho da classificação. Outro ponto a ser ressaltado foi a dificuldade de separação entre Formação Campestre e algumas atividades antrópicas como a silvicultura em estágio inicial e pastagens.

Meneses e Almeida (2012) ressaltam que a delimitação dos diferentes polígonos de cada classe na imagem é o algoritmo de classificação digital, mas quem constrói a legenda do mapa temático é o analista. A classificação de imagens deve, portanto, ser vista como um processo estatístico e probabilístico que tenta ao máximo aproximar o mapa digital à realidade. $\mathrm{O}$ resultado da classificação deve ser avaliado com base no desempenho do classificador proposto e validado por critérios numéricos para estimar a precisão e a sua acuracidade.

A definição de classes, representada na Figura 5, foi feita utilizando-se o método de edição vetorial para corrigir erros de classificação em algumas áreas. Estes erros de classificação ocorrem 
devido à semelhança de resposta espectral entre os alvos. O dado matricial foi exportado para vetorial e ajustado os polígonos e troca de uma classe temática por outra indevidamente classificada. A checagem foi feita por meio da interpretação do analista utilizando como superfície de fundo o mosaico (R5G4B3).

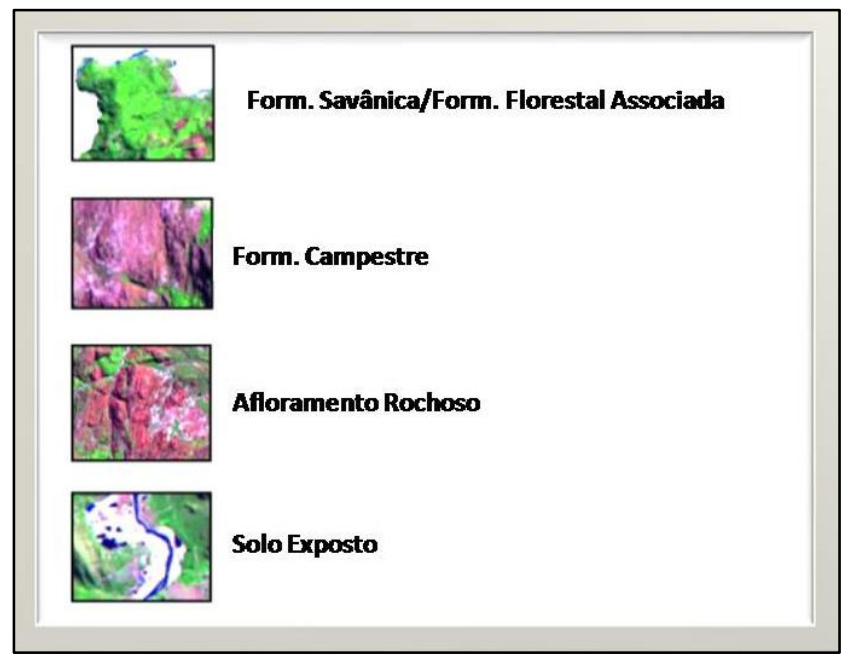

Figura 5: Exemplo da Amostras para a Classificação de uso e ocupação do terreno.

Visando aprimorar o resultado obtido na classificação multispectral do mapeamento de uso e ocupação do terreno, utilizou-se o coeficiente Kappa extraído da matriz de erro obtida pelo MultiSpec. O valor do coeficiente de Kappa, é comparado em classes de acurácia sendo que de 80\% a 100\% a classificação é reconhecida como excelente (LANDIS; KOCH, 1977). Considerando esta margem nesta pesquisa atingiu-se o índice Kappa superior a 95\%. Cinco mapas de uso e ocupação do terreno foram gerados com as 4 classes de representação para os anos de 1994, 1999, 2003, 2009, 2011 para a área do PEBI e sua ZA segundo parâmetros metodológicos apresentados. As informações obtidas do terreno foram tabuladas (Tabela 1), expressas suscintamente de forma gráfica nas Figuras 6 para área do PEBI e, figura 7 para sua ZA. Foram representadas em mapas de distribuição de classes de uso e ocupação do terreno por ano nas Figuras 8, 9, 10, 11 e 12.

\section{RESULTADOS}

As modificações ocorridas no PEBI e em sua zona de amortecimento está vinculada ao extrativismo mineral e vegetal e `a pecuária extensiva, principalmente aquela realizada em "terras de bolo". Soma-se a isso pressões antrópicas típicas do urbano e rural que margeiam as UCs. Uma pressão, já identificada no Alto Jequitinhonha, mas recente na área de estudo é a silvicultura, observada em setores de ZA bem próximos ao limite do parque. 
Para a área do PEBI, de forma geral, ao longo do período analisado, nota-se uma tendência de aumento das classes Formação Campestre (tênue) e Afloramento Rochoso. Há tendência de decrescimento nas classes Formação Savânica/Florestal associada e Solo Exposto (Tabela 1, Figura 6). Portanto, há uma relação inversa nas tendências entre as Formação Savânica/Florestal associada e Formação Campestre quanto a mensuração de suas áreas.

Tabela 1: Distribuição das Classes de Uso e Ocupação do Terreno do Parque Estadual do Biribiri.

\begin{tabular}{|c|c|c|c|c|c|c|c|c|c|c|}
\hline \multicolumn{11}{|c|}{ Distribuição das Classes de Uso e Ocupação do Terreno do Parque Estadual do Biribiri } \\
\hline \multirow{2}{*}{ Classes } & \multicolumn{2}{|c|}{1994} & \multicolumn{2}{|c|}{1999} & \multicolumn{2}{|c|}{2003} & \multicolumn{2}{|c|}{2009} & \multicolumn{2}{|c|}{2011} \\
\hline & Área (ha) & Porc. $(\%)$ & $\begin{array}{l}\text { Área } \\
\text { (ha) }\end{array}$ & Porc. $(\%)$ & $\begin{array}{l}\text { Área } \\
\text { (ha) }\end{array}$ & Pore. $(\%)$ & $\begin{array}{l}\text { Área } \\
\text { (ha) }\end{array}$ & Porc.(\%) & $\begin{array}{l}\text { Área } \\
\text { (ha) }\end{array}$ & Porc.(\%) \\
\hline $\begin{array}{l}\text { Formação } \\
\text { Savânica/Florestal } \\
\text { Associada }\end{array}$ & 6180,5 & 35,46 & 4724,0 & 27,10 & 7102,2 & 40,75 & 4927,1 & 28,27 & 3809,9 & 21,86 \\
\hline $\begin{array}{l}\text { Formaçāo } \\
\text { Campestre }\end{array}$ & 9276,1 & 53,22 & 10952,9 & 62,84 & 8911,9 & 51,13 & 10214,0 & 58,60 & 10172,1 & 58,36 \\
\hline $\begin{array}{l}\text { Afloramento } \\
\text { Rochoso }\end{array}$ & 1881,2 & 10,79 & 1664,8 & 9,55 & 1387,4 & 7,96 & 2227,2 & 12,78 & 3412,7 & 19,58 \\
\hline Solo Exposto & 91,2 & 0,52 & 87,3 & 0,50 & 27,5 & 0,16 & 60,7 & 0,35 & 34,2 & 0,20 \\
\hline Total & 17429,0 & 100,00 & 17429,0 & 100,00 & 17429,0 & 100,00 & 17429,0 & $100,00 \%$ & 17429,0 & 100,00 \\
\hline \multicolumn{11}{|c|}{ Zona de Amortecimento } \\
\hline \multirow{2}{*}{ Classes } & \multicolumn{2}{|c|}{1994} & \multicolumn{2}{|c|}{1999} & \multicolumn{2}{|c|}{2003} & \multicolumn{2}{|c|}{2009} & \multicolumn{2}{|c|}{2011} \\
\hline & Área (ha) & Porc.(\%) & $\begin{array}{l}\text { Área } \\
\text { (ha) }\end{array}$ & Porc.(\%) & $\begin{array}{l}\text { Área } \\
\text { (ha) }\end{array}$ & Porc. $(\%)$ & $\begin{array}{l}\text { Área } \\
\text { (ha) }\end{array}$ & Porc.(\%) & $\begin{array}{l}\text { Área } \\
\text { (ha) }\end{array}$ & Porc.(\%) \\
\hline $\begin{array}{l}\text { Formação } \\
\text { Savấnica/Florestal } \\
\text { Associada }\end{array}$ & 29781,9 & 48,88 & 25464,1 & 41,79 & 32320,2 & 53,05 & 26699,8 & 43,82 & 21454,3 & 35,21 \\
\hline Formação Campestre & 22069,7 & 36,22 & 29415,0 & 48,28 & 19872,6 & 32,62 & 27950,8 & 45,88 & 28483,4 & 46,75 \\
\hline $\begin{array}{l}\text { Afloramento } \\
\text { Rochoso }\end{array}$ & 7782,8 & 12,77 & 5308,3 & 8,71 & 8189,7 & 13,44 & 5659,1 & 9,29 & 10481,6 & 17,20 \\
\hline Solo Exposto & 1292,4 & 2,12 & 739,3 & 1,21 & 544,3 & 0,89 & 617,1 & 1,01 & 507,5 & 0,83 \\
\hline Total & 60926,8 & 100,00 & 60926,8 & 100,00 & 60926,8 & 100,00 & 60926,8 & 100,00 & 60926,8 & 100,00 \\
\hline \multicolumn{11}{|c|}{ Zona de Amortecimento e Área do Parque Estadual do Biribiri } \\
\hline \multirow{2}{*}{ Classes } & \multicolumn{2}{|c|}{1994} & \multicolumn{2}{|c|}{1999} & \multicolumn{2}{|c|}{2003} & \multicolumn{2}{|c|}{2009} & \multicolumn{2}{|c|}{2011} \\
\hline & $\begin{array}{l}\text { Área } \\
\text { (ha) }\end{array}$ & Porc. $(\%)$ & $\begin{array}{l}\text { Área } \\
\text { (ha) }\end{array}$ & Porc.(\%) & $\begin{array}{l}\text { Área } \\
\text { (ha) }\end{array}$ & Porc.(\%) & $\begin{array}{l}\text { Área } \\
\text { (ha) }\end{array}$ & Porc. $(\%)$ & $\begin{array}{l}\text { Área } \\
\text { (ha) }\end{array}$ & Porc. $(\%)$ \\
\hline $\begin{array}{l}\text { Formação } \\
\text { Savânica/Florestal } \\
\text { Associada }\end{array}$ & 35962,3 & 45,90 & 30188,2 & 38,53 & 39422,4 & 50,31 & 31626,9 & 40,36 & 25264,2 & 32,24 \\
\hline Formação Campestre & 31345,8 & 40,00 & 40367,9 & 51,52 & 28784,5 & 36,74 & 38164,8 & 48,71 & 38655,5 & 49,33 \\
\hline $\begin{array}{l}\text { Afloramento } \\
\text { Rochoso }\end{array}$ & 9664,0 & 12,33 & 6973,1 & 8,90 & 9577,1 & 12,22 & 7886,3 & 10,06 & 13894,3 & 17,73 \\
\hline Solo Exposto & 1383,6 & 1,77 & 826,6 & 1,05 & 571,7 & 0,73 & 677,8 & 0,87 & 541,7 & 0,69 \\
\hline Total & 78355,7 & 100,00 & 78355,7 & 100,00 & 78355,7 & 100,00 & 78355,7 & 100,00 & 78355,7 & 100,00 \\
\hline
\end{tabular}




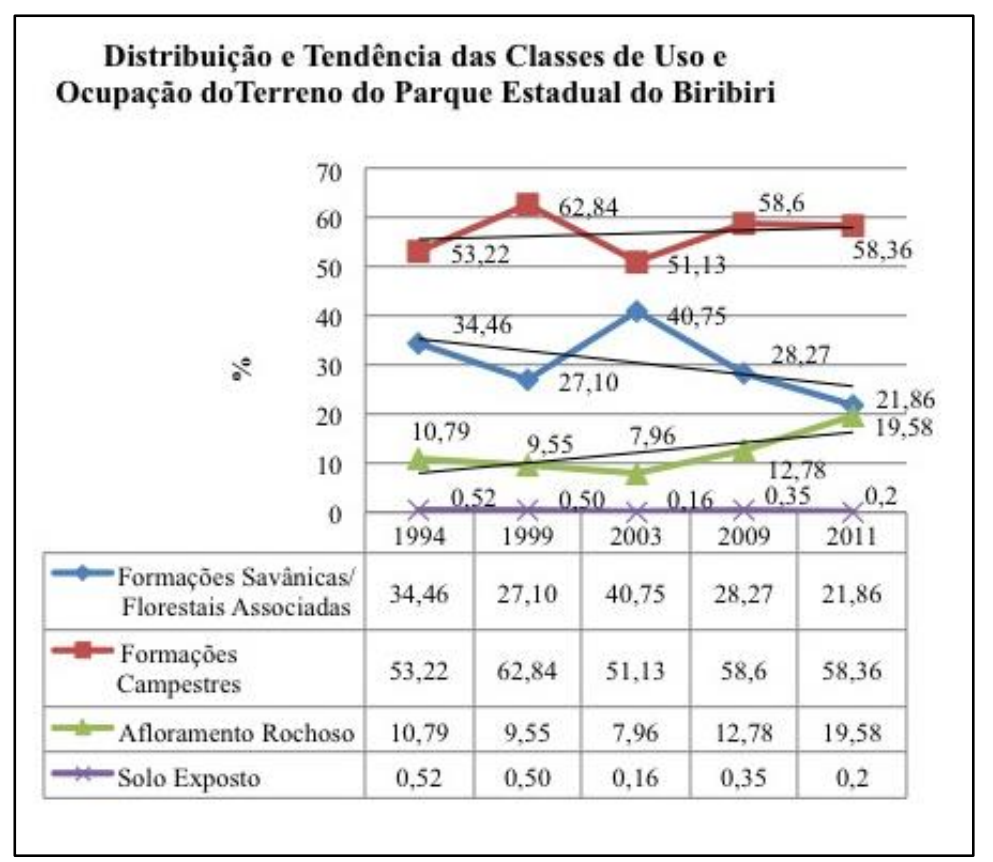

Figura 6: Distribuição e tendência das classes de Uso e Ocupação do terreno no PEBI entre 1994 e 2011.

Na Formação Campestre os ápices de áreas ocupadas aconteceram nos anos de 1999 e 2009 e os ápices da Formação Savânica/Florestal associada acontece no ano de 2003, sendo que a partir daí ocorre uma diminuição progressiva desta classe até o ano de 2011. Esta informação coincide com dados de incêndios florestais ocorridos na área entre 2007 e 2011 apresentados por Ávila e Souza (2012). A exposição do terrenos decorrente dos incêndios condicionou o aumento da classe Afloramento Rochoso entre 2003 e 2011 pela perda da cobertura vegetal. Cabe ressaltar que, apesar da alternância entre as formações Savânica/Florestal associada e Campestre esta última é predominante em extensão areal ao longo de todos os anos analisados. A classe Solo Exposto apresenta uma tendência de diminuição de área e comparada as demais, é a menos expressiva na área do PEBI.

Quanto a ZA do PEBI (Tabela 2, Figura 7) a realidade de tendências apresentadas para parque ocorrem na mesma relação que para a ZA. A alternância entre as formações Campestre e Savânica/Florestal associada também é perceptível mas suas extensões areais são mais próximas levando, inclusive, a sobreposição entre as formações (Figura 7), num ambiente menos tendencioso a uma delas. Ainda pode ser observado uma relação inversa entre as classes Afloramento Rochoso e Formação Campestre. 


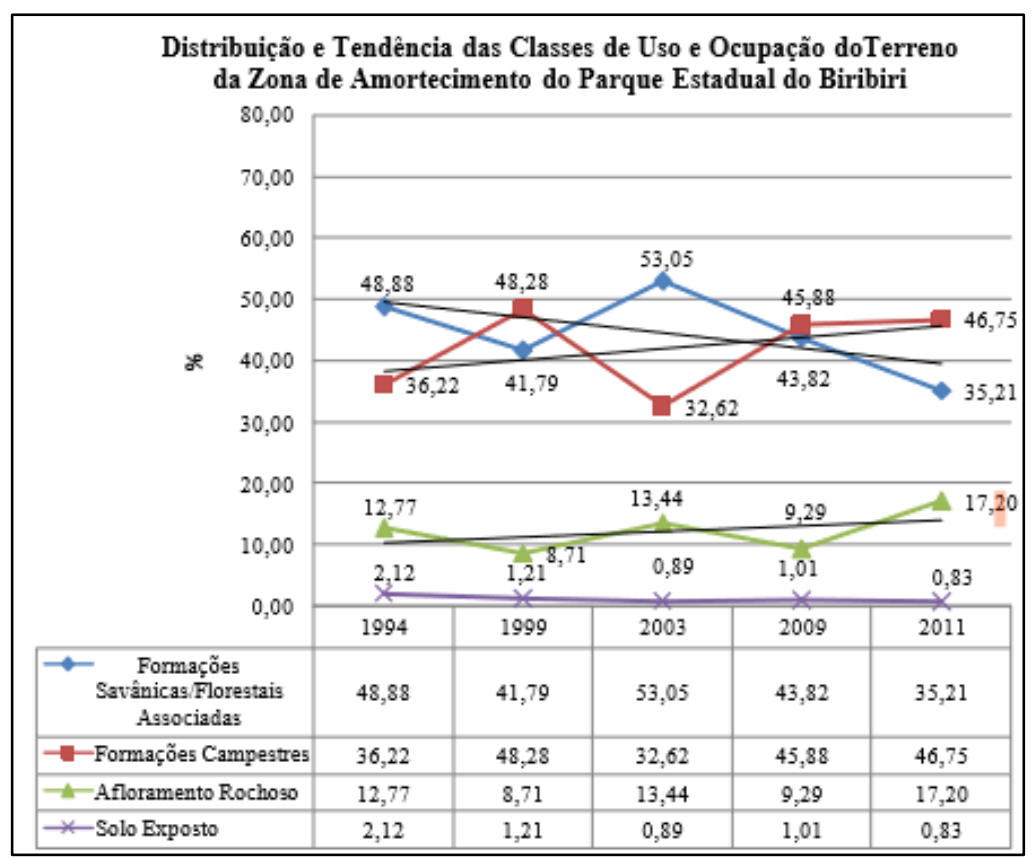

Figura 7: Distribuição e tendência das classes de Uso e Ocupação do terreno na ZA do PEBI entre 1994 e 2011.

Os picos apresentados nos anos de 1999, 2003 e 2009 possibilitam uma interpretação quanto a sucessão ecológica nesta região: entre 1994 e 1999 há a diminuição da Formações Savânica/ florestais associada, aumento da Formação Campestre (gramíneas) sem aumento da classe Solo Exposto. A evolução observada na Figura 7, entre o ano de 1999 e 2003 há um aumento Formação Savânica/ Florestal associada em relação a Formação Campestre. Este fato é justificado por Amaral et al. (2013) ao observar um aumento significativo no número de indivíduos da vegetação arbustivoarbórea colonizadora no PEBI por um período de dois anos, o que evidência a importância da regeneração natural no processo de recomposição de área degradadas.

Outra preocupante fonte de alteração do terreno são os incêndios florestais, que são entendidos como todo fogo sem controle que incide sobre qualquer forma de vegetação tanto por ação antrópica (intencional ou negligência) como por causa natural (raios) causando dano humano e/ou ao meio ambiente (ÁVILA; SOUZA 2012)

Para Santos et al. (2006) a maior parte dos incêndios é causada pelo homem e fatores climáticos como déficit hídrico, vento e/ou o relevo do local influenciam a propagação do fogo e determinam os seus efeitos. Quantificações de áreas atingidas ainda requerem uma melhor discussão no que concerne aos resultados e métodos de análise. Segundo Santos et al. (2006), entre 1998 e 2002, Minas Gerais teve uma área de 55.506 ha atingida por incêndios. Divergente desta informação, Lima (2000) afirma que no ano de 1999 as UCs do estado contabilizaram 52.000 ha de área queimada, indicando que esta questão e sua discussão é de grande relevância para manutenção da qualidade das UCs. 
Independente do processo e fator de alteração da qualidade ambiental de um terreno, faz-se necessário o conhecimento dos componentes do meio físico, base para elaboração de medidas e ações que irão culminar na manutenção ou mesmo reconstituição da qualidade ambiental de uma determinada área. Para isso, tecnologias espaciais que fornecem dados do terreno de forma sinóptica e repetitiva apresentam-se com um instrumento básico auxiliar no levantamento de recursos naturais e suas alterações.

Os sensores orbitais TM/ Landsat têm fornecido dados periódicos e constantes, o que garante a possibilidade do monitoramento de uma determinada região.

O conjunto paisagem natural é constituído por fitofisionomias nativas predominantes na região, que, neste trabalho, foram: Formação Savânica/Florestal Associada; Formação Campestre e Afloramento Rochoso. A Formação Savânica e a Formação Florestal foram unificadas por apresentarem, tanto na escala de mapeamento e quanto na qualidade da imagem, comportamentos bastante parecidos, o que dificultou o desempenho da classificação. A paisagem antropizada é formada pela alteração do habitat nativo em decorrência de ações do homem, direta ou indiretamente, classificada neste trabalho, principalmente, como Solo Exposto que pode compreender as seguintes atividades: urbanização, área degradada (área de empréstimo, voçorocamento, garimpo) além de momentos de estágio inicial de preparação do solo para silvicultura e pastagens. Em decorrência do processo natural de regeneração ou devido estágios de desenvolvimento inicial de pastagens e/ou silvicultura, a resposta espectral condicionou a uma interpretação da classe Formação Campestre.

\subsection{Análise temporal da classe Solo Exposto}

A área total da classe solo exposto teve o mesmo comportamento no parque e na sua ZA, tendendo a diminuição de 1.383 ha para 541 ha entre 1994 e 2011, respectivamente e encontram-se representadas nas figuras 8, 9, 10, 11, e 12). Representam garimpo, áreas de pastagem (delimitadas geometricamente pelo desmatamento, edificação da UFVJM, áreas de empréstimo para nivelamento de rodovia federal (BR 367), área destinada a aterro controlado cidade de Diamantina, construção de aeroporto (Figura 13). Na ZA esta classe concentra-se a Norte, nas imediações do povoado de Maria Nunes e nas margens do rio Caeté Mirim. A Leste sua ocorrência associa-se a áreas de extrativismo mineral, no Garimpo Lavra do Mato, às margens do rio Jequitinhonha, assim como a Oeste, nas cabeceiras do rio Pinheiros. Em todas essas áreas as marcas do garimpo estão impressas na paisagem e que em 1994 (Figura 9) essa atividade já estava sendo alvo de intensa fiscalização, a qual o coibiu regionalmente.

As manchas da classe solo exposto estão concentradas na porção Norte do parque (Figuras 8; 13) onde há ocorrência de solos expostos nas unidades de Neossolos justifica-se por serem 
pedoambientes de espécies variadas de Sempre Viva, que tem como parte de seu manejo, pelas comunidades locais, a utilização do fogo para a sua rebrota. Apresentam, ainda, potencial para o extrativismo mineral do diamante e ouro (secundário).

\subsection{Análise temporal da classe Afloramento Rochoso}

Esta classe possui uma tendência de aumento de área tanto no parque quanto em sua ZA que totalizam 9.664 ha para 13.894 ha entre 1994 e 2011 respectivamente. Os meses referentes as imagens são de Maio a Setembro, meses notadamente de déficit hídrico o que pode levar a uma maior exposição de rocha frente a retração da vegetação. Na área do parque há uma maior concentração em sua porção Norte (Serra da Apolônia) e na ZA há manchas com fragmentação desta classe expostas na direção NW-SE, semelhante a direção da foliação regional das rochas do Supergrupo Espinhaço (Figura 12).

\subsection{Análise temporal da classe Formação Campestre}

Esta classe possui uma tendência de aumento de área, semelhante ao comportamento da classe Afloramento Rochoso, tanto no parque quanto em sua ZA que totalizam em 31.345 ha em 1994 para 38.655 ha em 2011.

As formações campestres são as mais expressivas no PEBI. Em 2011, recobriam cerca de 10.172 ha, equivalente a $58 \%$ de sua área predominante na porção Sul e central do PEBI. O domínio dessa classe na área do parque é ligada a fatores naturais como solos rasos, pobres (quartzarênicos), altitudes elevadas. Outro fator importante a ser considerado é que após incêndios florestais há a diminuição do sombreamento realizado pelos estratos herbáceos e arbóreos, condicionando assim o rápido crescimento de gramíneas as quais são interpretadas como Formações Campestres. Essa realidade justifica a não interpretação de um aumento nas áreas de solo exposto, como evidenciado na Tabela 1 e Figuras 6 e 7.

Importante ressaltar que manchas da Formação Savânica/ Florestal associada ocorrem normalmente em presença de cursos d'agua. A Norte da ZA esta formação quase não está presente fator condicionado as baixa cotas altimétricas, dando lugar ao Cerrado. Entretanto, a partir de 2009 manchas desta classe aparecem nesta porção Norte devido a retirada da cobertura vegetal para uso antrópico: pastagens e áreas destinadas silvicultura foram observadas (Figuras 11; 12), mas devido a ausência do solo exposto foram interpretadas como Formação Campestre. Na porção Oeste e Sudeste nas cotas altimétricas mais elevadas em associação s Formação Savânica/ Florestal. 


\subsection{Análise temporal da classe Formação Savânica/Florestal associada}

Esta classe possui uma tendência de diminuição de área de abrangência, tanto no parque quanto em sua ZA que totalizam em 35.962 ha em 1994 (Figura 8) para 25.264 ha em 2011 (Figura 12) . A formação Savânica/ florestal associada ocorrem ao longo de toda a área limítrofe do parque coincidindo com os cursos dos rios Caeté Mirim, Pinheiro e Jequitinhonha além de acompanhar cursos d'água hierarquicamente inferiores dentro da área do parque.

As interpretações realizadas a partir da imagem obtida em 1999 evidenciam modificações nos extratos vegetacionais no parque; a Formação Savânica/Florestal associada apresenta uma perda de aproximadamente $8 \%$, ou seja, uma diminuição de 1.461 ha, que pode estar vinculada a retirada de madeira, aos incêndios florestais e às características de uma vegetação decídua uma vez que a imagem analisada é do mês de Setembro, momento em que o índice pluviométrico médio fica abaixo dos 50mm, segundo dados climatológicos entre 1977 a 2006 (VIEIRA et al., 2010; FERREIRA; SILVA, 2012).

A diminuição das Formação Savânica/ Florestal associada acontece de forma homogênea (parque + ZA) entre 1994 e 1999. Esse fato conduz a uma interpretação de que o principal fator dessa diminuição foi o incêndio florestal, uma vez que é comum em todo o Alto Jequitinhonha a utilização do fogo como instrumento de limpeza de pasto. Entre 1999 e 2003 nota-se aumento desta formação na área pesquisada que, segundo Amaral et al. (2013), trata-se de uma evidência importante de condução da regeneração natural (estratos herbáceos-arbustivos) no processo de recomposição no PEBI e entorno. Em seu estudo, os autores relatam que em um período de dois anos houve uma sobreposição dos estratos herbáceos-arbustivos sobre as gramíneas.

A partir de 2003 tem-se uma queda crescente desta classe associada sem sua retomada ate o ano de 2011 e uma tendência de estabilização da Formação Campestre. Este fato relaciona-se aos sucessivos incêndios florestais nos anos de 2007-2011 vinculados a área do parque (ÁVILA; SOUZA, 2012). Na ZA, nota-se uma perda progressiva desta formação principalmente na região Norte, onde as pastagens e as florestas plantadas, dada a qualidade / espessura do solo, passam a ocupar áreas, seja como Formação Campestre seja como solo exposto (Figura 12). 


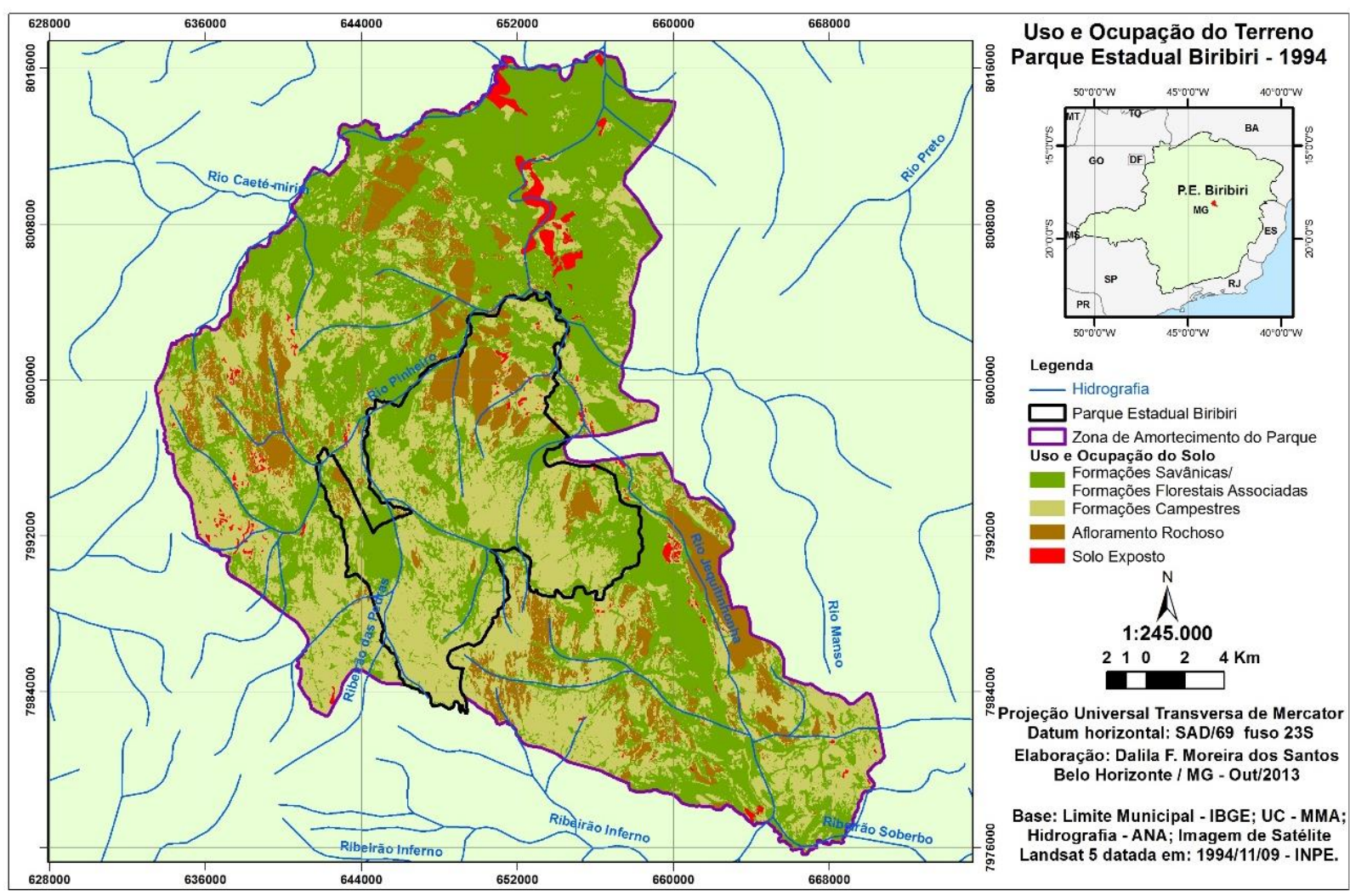

Figura 8: Mapa de Uso e Ocupação do terreno para o PEBI e entorno para 1994.

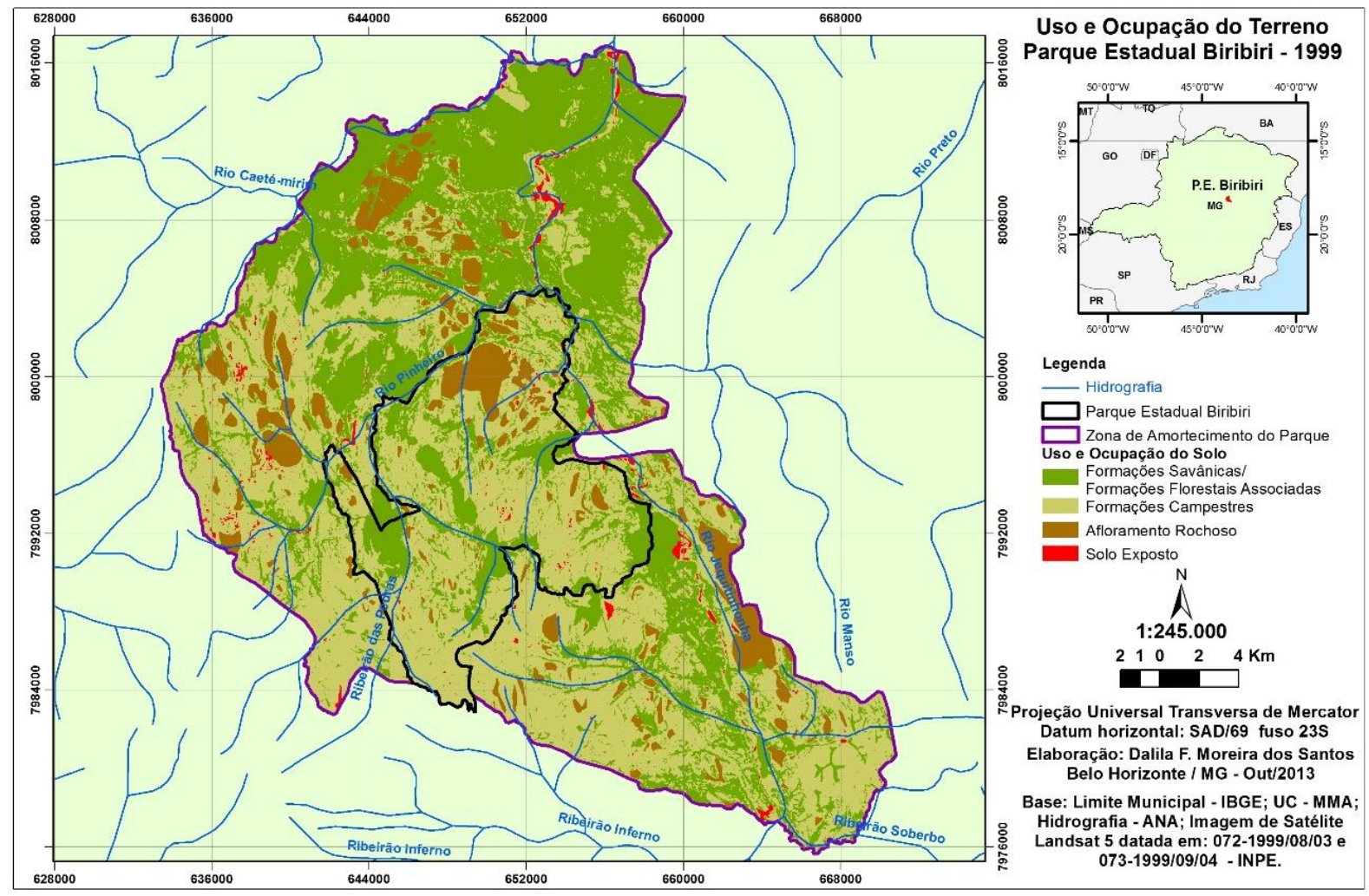

Figura 9: Mapa de Uso e Ocupação do terreno para o PEBI e entorno para 1999. 


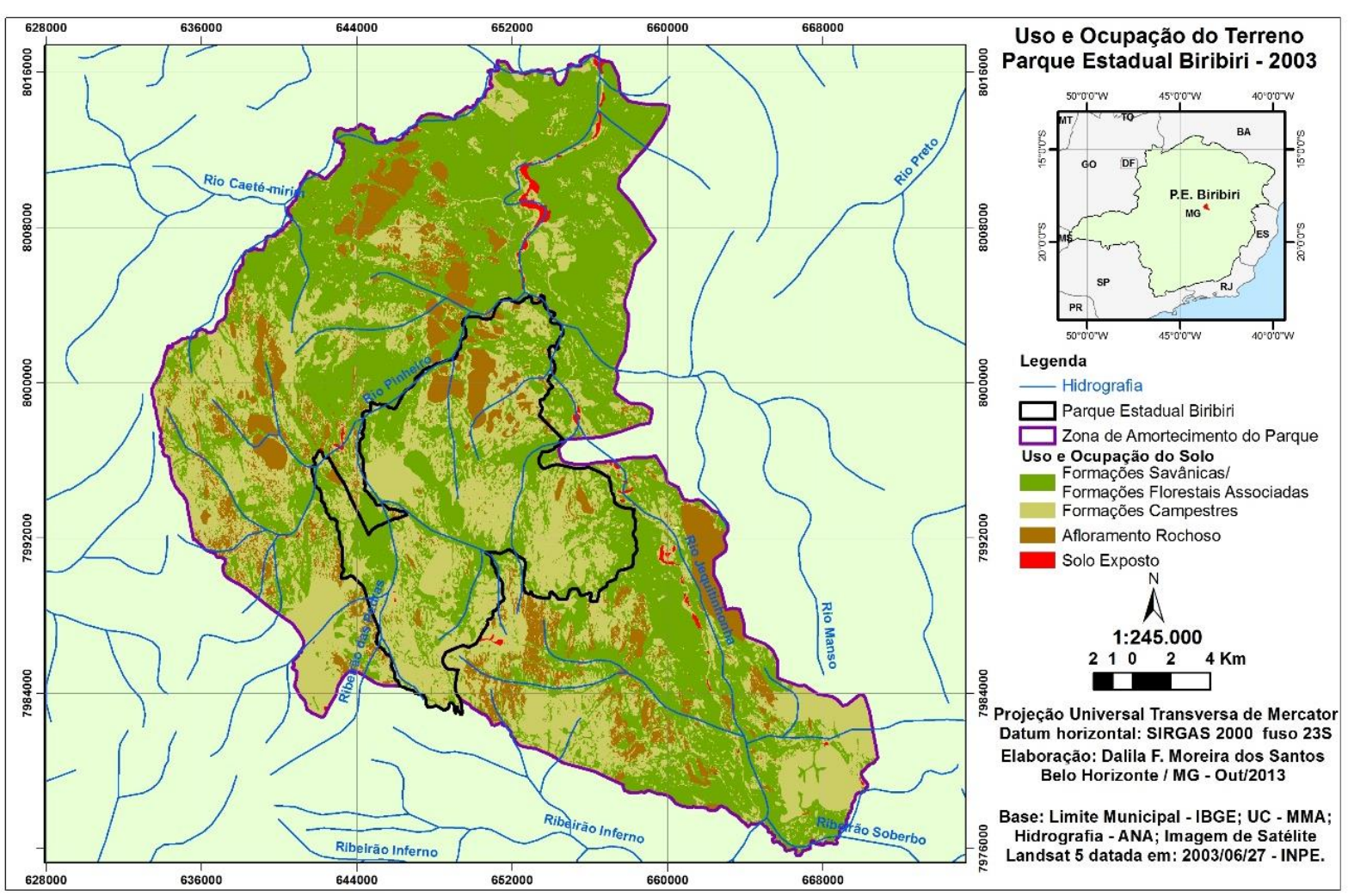

Figura 10: Mapa de Uso e Ocupação do terreno para o PEBI e entorno para 2003.

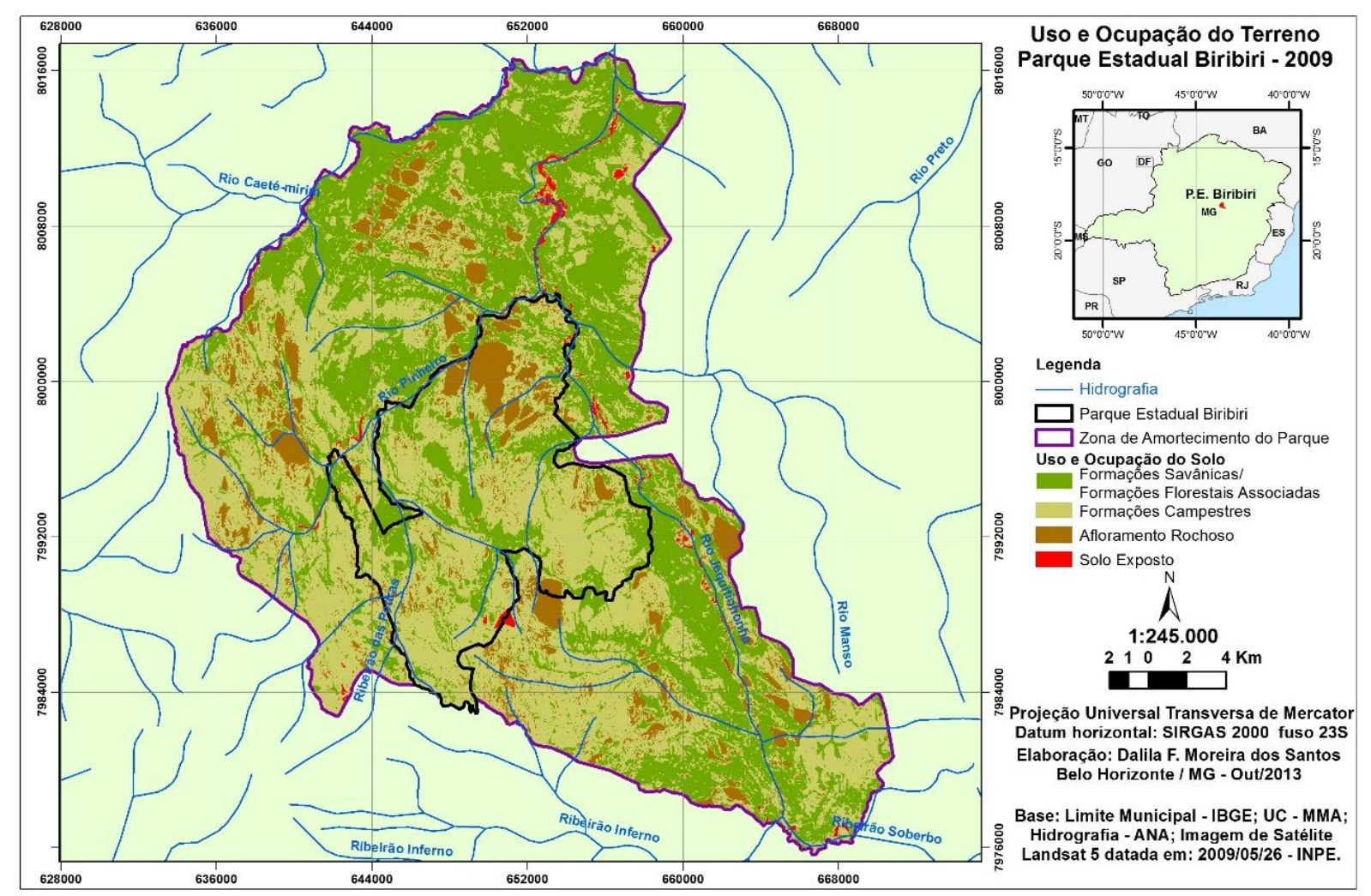

Figura 11: Mapa de Uso e Ocupação do terreno para o PEBI e entorno para 2009. 


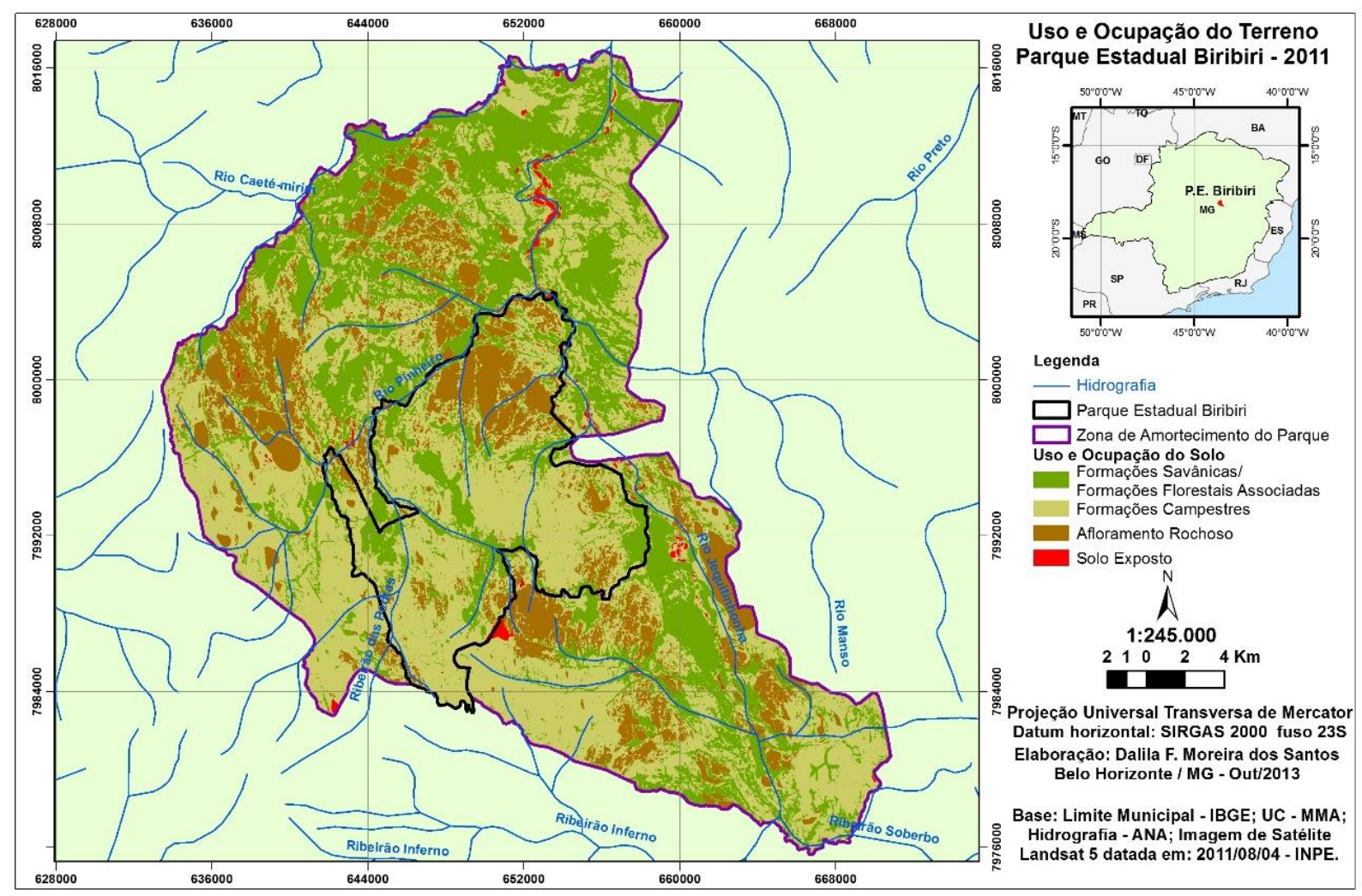

Figura 12: Mapa de Uso e Ocupação do terreno para o PEBI e entorno para 2011.
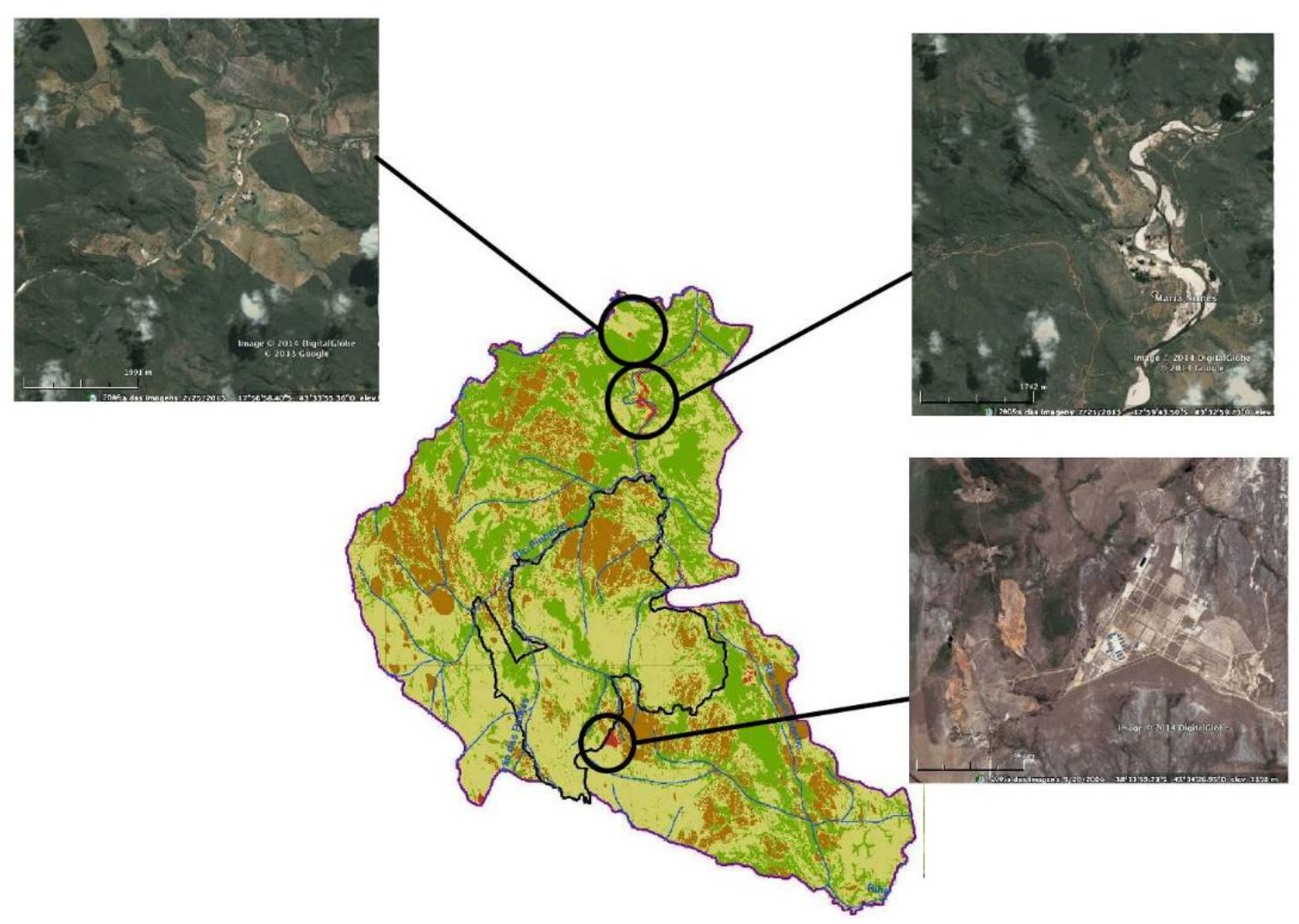

Figura 13: Localização de categorias de análise no Mapa de Uso e Ocupação de 2011, exemplificadas com imagens do Google Earth. Canto esquerdo superior - área de pastagem degradada em vertente e garimpo no leito do rio Caeté Mirim. Canto superior direito: garimpo ao longo do rio Jequitinhonha, próximo a Comunidade de Maria Nunes. Canto Inferior direito: imagem do ano de 2005 da cascalheira (área do PEBI) e Campus da UFVJM. 


\section{CONCLUSÕES}

Comparando resultados para o período de 1994-2011 para o PEBI e sua ZA, nos mapas de uso e ocupação foi possível traçar tendências para a dinâmica das classes analisadas. $\mathrm{Na}$ área do parque há uma tendência de estabilização da Formação Campestre e um decréscimo da classe Formação Savânica/Florestal Associada. Esta diminuição está condicionada ao tempo necessário a sua regeneração uma vez que as imagens analisadas foram obtidas nas estações mais secas aliadas a recorrência de incêndios florestais. A tendência de diminuição mais acentuada da Classe Savânica/Florestal Associada pode estar condicionada ainda a atual realidade fundiária do parque cuja falta desta regularização acentua o conflito gerado quanto ao uso do espaço levando, consequentemente, a incêndios propositais. Deve ainda ser levado em consideração a realidade de seu limite Leste, o qual é delimitado por uma rodovia federal, o que expõe o PEBI a uma condição de alerta ao uso irregular de seus limites.

Os mapas temporais evidenciaram uma tendência de estabilização para a classe Solo Exposto. Mesmo em período anterior a criação do parque essa classe apresentou menos de $1 \%$ de área nos limites do parque.

A área abrangida pelo parque e sua ZA apresentou uma pequena influência de atividades antrópicas, com destaque para áreas de pastagens abandonadas, garimpo, urbanização, áreas de empréstimo (construção da BR 367 e pavimentação do Campus da UFVJM) e silvicultura.

A realidade exposta pela análise temporal do uso e ocupação do terreno discorda das informações desta natureza contida no Plano de Manejo da UC, que afirma que atividades de cunho tradicional são fatores determinantes para a perda de qualidade ambiental em sua área. Todas as atividades realizadas na área do parque que apresentava um caráter de tradicionalidade na sua grande maioria, com exceção de pequenas áreas de garimpo, foi totalmente regeneradas. Essa realidade evidencia que a coleta de flores e pecuária de solta, por exemplo, não podem ser classificadas de forma generalista como atividades degradadoras, como explicitado nos planos de manejo.

O PEBI, desde sua criação, apresenta uma área ambientalmente idônea, o que justificou, em parte, sua criação. Porém a proibição de atividades consideradas aqui tradicionais e a falta de possibilidades/alternativas implicaram no surgimento de conflitos socioambientais que aparentemente encontram-se resolvidos ou adormecidos. Abstendo a uma discussão sobre a real necessidade de reconhecimento de comunidades tradicionais e de entendimento de seus direitos e deveres, após a realização desse trabalho fica claro que as unidades de conservação de uso integral devem ter subsídios legais para aliar as necessidades socioculturais, econômicas e materiais das populações de seu entorno ao conjunto de demandas externas que envolvem as políticas de preservação de UC'S. Dessa forma, a economia e a cultura local estarão diretamente associadas às 
políticas de preservação, o que permitiria a sobrevivência da cultura material e imaterial dessas populações, assim como a permanência das mesmas em áreas de preservação ambiental, inclusive naquelas consideradas áreas de máxima proteção e as de preservação ambiental, inclusive naquelas consideradas áreas de proteção máxima.

\section{AGRADECIMENTOS}

MSM agradece a FAPEMIG (Fundação de Amparo à Pesquisa do Estado de Minas Gerais) por bolsa de doutorado e BMG agradece 'a FAPEMIG pelo apoio financeiro ao projeto: Caracterização $e$ Gestão Sistêmica das Paisagens da Reserva da Biosfera da Serra do Espinhaço.

\section{REFERÊNCIAS}

ABREU, A.A. Análise Geomorfológica: reflexão e aplicação (Uma contribuição ao conhecimento das formas de relevo do Planalto de Diamantina- MG). 1982, 296 p. Tese de Livre Docência. FFLCH, Universidade de São Paulo, São Paulo, 1982.

AMARAl, W. G., PEREIRA, I. M., MACHADO, E. L. M., OLIVEIRA, P. A., DiAS, L. G., MUCIDA, D. P., AMARAL, C. S. Relação das espécies colonizadoras com as características do substrato em áreas degradadas na serra do espinhaço meridional. Bioscience Journal, v. 29, n. 5, 2013.

ÁVILA, G. C.; SOUZA, D. E. . Incêndios Florestais no Parque Estadual do Biribiri e entorno imediato, entre 2007 e 2011 e suas relações com a presença humana. In: Congresso Brasileiro de Unidades de Conservação, 2012, Natal. Anais... VII Congresso Brasileiro de Unidades de Conservação, 2012.

AZEVEDO, A. A.; GOULART, M. F.; SILVA, J. A. S. VILHENA, C. F. Mosaico de Unidades de Conservação do Espinhaço: Alto Jequitinhonha - Serra do Cabral. (Relatório Técnico). Diamantina: Instituto Biotrópicos, 2009.

CENTENO, J. A. S. Sensoriamento Remoto e Processamento de Imagens Digitais. 2.ed. Curitiba: Universidade Federal do Paraná (UFPR), 2004, 168p.

FERREIRA, V. O.; SILVA, M. M. O Clima da Bacia do Rio Jequitinhonha, em Minas Gerais: Subsídios para a Gestão de Recursos Hídricos. Revista Brasileira de Geografia Física, v. 5, n. 2, p. 302-319, 2012.

GUIMARÃES, R. M. Seleção de geoindicadores para determinação de áreas de fragilidade face às pressões antrópicas: contribuição da análise geossistêmica e da ecologia da paisagem no Espinhaço Meridional. 2004, 183f. Dissertação (Mestrado em Geografia) - Universidade Federal de Minas Gerais, Departamento de Geografia. Belo Horizonte 2004.

LANDIS, J.R.; KOCH, G.G. The measurement of observer agreement for categorical data. Biometrics, v. 33, n. 1, p. 159-174, 1977.

LIMA, G. S. A prevenção de incêndios florestais no estado de Minas Gerais. Floresta, v. 30, n. 12 , 2000. 
MELGAÇO, J. Geomorfologia, educação ambiental e produção agrícola em municípios do Alto Jequitinhonha - Serra do Espinhaço Meridional - MG. 79 p. 1999. Dissertação (Mestrado em Geografia). Universidade Federal de Minas Gerais. Belo Horizonte, 1999.

MENESES, P. R.; ALMEIDA, T. (Org.) Introdução ao Processamento de imagens de sensoriamento remoto. Brasília: Universidade de Brasília. 2012. Disponível em: <http://www.cnpq.br/documents/10157/56b578c4-0fd5-4b9f-b82a-e9693e4f69d8> Acesso em: 31 Jul. 2013.

MINAS GERAIS. Decreto no 39.909, de 22 de Setembro de 1998. Cria o Parque Estadual do Biribiri e dá outras providências. Belo Horizonte, Minas Gerais, 1998

MORAIS, M.S. A Realidade Socioambiental Imposta `as comunidades locais pela Criação e Implementação dos Parques Estaduais do Biribiri e Rio Preto. 2014. 230 f. Tese de Doutorado em Geografia. Departamento de Geografia, Instituto de Geociências, Universidade Federal de Minas Gerais, Belo Horizonte, 2014.

MORAIS, M.S., GONTIJO, B., PIUZANA, D., DUPIN, P. Comunidades e unidades de conservação: a realidade dos conflitos em comunidades do entorno dos parques estaduais do Rio Preto e Biribiri, Minas Gerais. OLAM - Ciência \& Tecnologia, Brasil, 13, jan. 2014. Disponível em: <http://www.periodicos.rc.biblioteca.unesp.br/index.php/olam/article/view/8048/5806.>Acesso em: 05 Mar. 2014.

RIBEIRO, J. F. R.; WALTER, B. M. T. Fitofisionomias do Bioma Cerrado. SANO, S. M; ALMEIDA, S. P (Org.) Cerrado, ambiente e flora. Planaltina: Embrapa, 1998.

SAADI, A. A Geomorfologia da Serra do Espinhaço em Minas Gerais e de suas Margens. Geonomos, Belo Horizonte, v.3, n.1, p.41-63, 1995.

SANTOS, J. F. et al.. Perfil dos incêndios florestais no Brasil em áreas protegidas no período de 1998 a 2002. Revista Floresta, v.36, n.1, Jan/Abr. 2006, Curitiba, PR.

SILVA, A. C. Diagnóstico e avaliação pedológica para o plano de manejo do Parque Estadual do Biribiri. Diamantina, SEMAD/IEF, 2004. 37p.

SILVA, A. C.; PEDREIRA, L. C. V. S. F.; ALMEIDA-ABREU, P. A. (Org.). Serra do Espinhaço Meridional: Paisagens e Ambientes. 1ed. Diamantina: UFVJM - Faculdade de Ciências Agrárias, 2005. 272p.

SILVA, M. L. Mapeamento, Estoque de Matéria Orgânica e Valor Ambiental das Turfeiras da Serra do Espinhaço Meridional - SdEM. Dissertação de Mestrado em Ciência Florestal. Universidade Federal dos Vales do Jequitinhonha e Mucuri. Minas Gerais, Diamantina 2012.

STCP ENGENHARIA DE PROJETOS LTDA. Plano De Manejo Do Parque Estadual Do Biribiri. Planejamento Da Unidade De Conservação. Volume I e II - Encarte 1. SDS-02/02 - Revisão Final. Curitiba - PR: Setembro, 2004a.

STCP ENGENHARIA DE PROJETOS LTDA. Plano De Manejo Do Parque Estadual Do Biribiri. Planejamento Da Unidade De Conservação. Volume I e II - encarte 2. SDS-02/02 - Revisão Final. Curitiba - PR: Setembro, 2004b. 
VIEIRA, J.P.G., SOUZA, M. D., TEIXEIRA, J. M., CARVALHO, F. D. Estudo da precipitação mensal durante a estação chuvosa em Diamantina, Minas Gerais. Revista Brasileira de Engenharia Agrícola e Ambiental, v. 14, n. 7, p. 762-767, 2010.

YANG, X. Satellite Monitoring of Urban Spatial Growth In the Atlanta Metropolitan Area. PE\&RS Photogrammetric Engineering \& Remote Sensing, v.68, n. 7. p. 725-734, 2002. 